\title{
SELECTED BIBLIOGRAPHY FROM THE SPECIAL COLLECTIONS DEPARTMENT OF THE COLLEGE OF THE BAHAMAS LIBRARY
}

\author{
Compilation by Angela Gottardi \\ Special Collections Librarian \\ The College of The Bahamas Library
}

\{This is a reader's bibliography and a work unto itself. It is not meant to support a work of research or any other work. The format used for this bibliography is presented in the following manner: title (in bold italics), author, publication information.

This style is a deliberate departure from that of APA to which other articles in this publication of College Forum are required to conform.

\section{INTRODUCTION}

In the Special Collections Department of The College of The Bahamas Library resides a little treasure trove of resources pertaining to The Bahamas, the West Indies and Africa. These collections hold a variety of printed materials: books, dissertations, research studies, government documents, journals, newspaper clippings and emphemera. The Bahamian Collection is the most extensive. Established in 1984, it serves the purpose of a research depository for The Bahamas, as the National Library is yet to be built. Officially, the National Archives is the depository for the historical records of the country. The Bahamas is fortunate in having a very fine archival institution, located on Mackey Street.

Titles included in the Bahamian Collection - Selected Bibliography are books chosen for their representational appeal. The intention was to represent a cross section of publications highlighting all aspects of The Bahamas. That was the primary criterion. The other consideration was motivational value. By this is meant the ability to tantalize the reader into discovering more about who, why and what has been printed to preserve, inform, entertain and contemplate the fascinating evolution of The Bahamas. Owing to the strong oral tradition of the country, the printed record of the people began somewhat later than in many other cultures. This, too, is of significance to the interested reader.

In August 1996, when I came to work at The College of The Bahamas as the Special Collections Librarian, I knew nothing of the colors, textures, and vitality of this country. A Foder's travel guide provided factual information and description and some enticing photographs. The context of Bahamian life was a mystery to me. As the authors of the books selected for this bibliography, I have grown more and more intrigued by this island archipelago. Thanks to the encoded voice of natives and, like myself, windblown curious wanderers, who have had the good fortune to arrive, if only for a short while, and partake, a cache of Bahamian wealth has been shared. 


\section{Aspects of Bahamian culture.}

Anastasia Elaine Dahl Smith. NY: Vantage Press, 1978.

This study examines the following topics: the forces and conditions which have impacted Bahamian culture, the achievements and accomplishments of the government since independence, the differences between city life and the family islands, and the important folk traditions practiced in The Bahamas today. Includes bibliography. 78 pages.

Bahamas. (Places and People of the World Series.)

Patricia E. McCulla. NY: Chelsea House, Publishers, 1988.

A good, consolidated factual look at The Bahamas in a global context. The text includes a map, an historical time-line and numerous photographs. Includes glossary and index. 104 pages.

Bahamas. (Insight Guides.)

Hans Hoefer. Singapore: APA Productions, 1987.

An Insight Guides travel publication. True to the series, Bahamas, is an in-depth, well written, and beautifully photographed survey which includes historical and cultural information, including chapters on New Providence and Nassau written by Gail Saunders. Travel tips, addresses of embassies and consulates and an extensive bibliography of Bahamiana expand the scope of the work. 306 pages.

\section{Bahamas between worlds.}

Dean Collingwood. Decatur, Illinois: White Sound, 1989.

The unique characteristics of Bahamians and the national development of The Bahamas is the focus of this somewhat provocative study. The relationships of The Bahamas to the U.S. and the Caribbean are examined. Inciudes appendix and bibliography. 121 pages.

\section{Bahamas Junkanoo. (Annual)}

Anthony Morley. Nassau Bahamas: Bahamas Far Eastern Publications, 1989.

A colorful pictorial describing the Junkanoo Festival and promoting The Bahamas. Distinctive Bahamian themes, Junkanoo style, are represented in photographs. 48 pages.

\section{Bain Town.}

Cleveland Eneas. Nassau Bahamas: Tripaul, Ltd. 1976, 1988.

Dr. Eneas' documentation of Bain Town from 1890 to 1970. Descendants of the Yorubas, from Nigeria, who called themselves N'ongas are highlited. The boundaries of Bain Town are traced. Trees, Christmas, women are some subjects of interest. Includes bibliography. 88 pages. 
Conch book. All you ever wanted to know about the queen conch.

Dee Carstarphen. Miami, Florida: Pen and Ink Press, 1982.

The influence of strombus gigas as food, tool, decoration and cultural icon.

Includes recipes. Includes bibliography. 75 pages.

\section{Cooking the Bahamian way and bush tea.}

Sylvia Laramore-Crawford. Nassau, Bahamas: Sylvia Laramore-Crawford, 1991.

Written in commemoration of the Columbus Quincentennial. Many traditional recipes for conch, chicken, okra, rice, souse and seafood dishes are included in this simple, down-to-earth collection. Basic bush teas and breads complete this truly Bahamian cookbook. Pineapple fritters add a tasty touch. 40 pages.

\section{Creative Bahamian cooking and menus.}

Elsa Miller and Leonard "Sonny" Henry. Kingston, Jamaica: Kingston Pub., reprint, 2nd revision 1994.

A cookbook for the more exotic palate. Recipes for pigeon and duck as well as barbeques, sauces, relishes, jams and beverages enhance the selections. Menus, glossary, measurements, household hints and substitutions comprise a helpful reference section. 86 pages.

\section{Dictionary of Bahamian English.}

John Holm. Cold Spring, New York: Lexik House, 1982.

A scholarly work with an extensive etymology and introduction analyzing the American, European and African elements of Bahamian English. Includes maps, glossary, list of informants as well as a substantial bibliography. 228 pages.

\section{Gourmet Bahamian Cooking.}

Marie Mendelson. Iowa City, Iowa: Best-Way Publishing Company, thirteenth printing, 1983.

Breads and desserts are an outstanding feature of this collection. Recipes for sapodilla pudding and ice cream, guava dumplings and benne cakes will make any Bahamian happy. Recipe rules, food equivalents and substitutions, cooking tips to maintain nutritive values in foods, along with hints and tricks for smart cooks provide additional useful information. Includes index. 286 pages.

Herbal medicine and home remedies: a potpourri in Bahamian culture. Portia Brown Jordan. Nassau, Bahamas: Nassau Guardian press, 1986.

The title bespeaks the contents. Folklore, pharmacy, poetry, plant propagation and recipes. The appendix includes anatomical and botanical illustrations, domestic measurements, and glossary. Includes index and bibliography. 172 pages.

How to be a true-true Bahamian: a hilarious look at life in The Bahamas. Patricia Glinton-Meicholas. Nassau, Bahamas: Guanima Press, 1994.

A Bahamian takes a comical look at her culture. One chapter, "National Personality," defines the Bahamian identity. Appearance, architecture and celebrations are samples of topics the author examines. 128 pages 
Junkanoo: a festival of The Bahamas.

E. Clement Bethel. London, England: Macmillan Caribbean, 1991.

Clement Bethel, who was the Chief Cultural Affairs Officer for The Bahamas, devoted this book to the Junkaoo celebration. This scholarly work explores historical, sociological and cultural aspects of the festival as it is celebrated in The Bahamas and, similarly, throughout the Caribbean area. Brent Malone's brilliant paintings colourfully illustrate the book. Includes index. 94 pages.

King conch: true, true Bahamian recipes.

De'ynza "King Conch" Burrows. Nassau, Bahamas: King Conch Int'l. Pub., 1979.

Seafood recipes from "King Conch." More conch recipes than imaginable; 18 types of conch chowder are included. Substitutions for conch, metric conversions, food quantities for serving large groups (from 25 to 100 guests), and a spice guide offer helpful suggestions. Includes index. 112 pages.

Obeah: including Bahamian Book of the dead, Bahamian black magic \& witchcraft. Carlton Robinson. Nassau, Bahamas: Carlton Robinson, 1995.

In this work Mr. Robinson offers a brief introduction to the African roots of

Obeah. Ten imaginative vignettes describe the Obeah Man's work. 36 pages.

\section{Old stories and riddles. Bahamiana culturama \#1.}

Mizpah Tertullien, Nassau, Bahamas: 1977.

The author of Psychologically Speaking put together this little book. Brer

Bookie and Brer Rabbie share their lessons. Tricky shows Shine Eye and Pretty Gal that "Not Everything in Clothes is People." Find out what has three eyes and can only see out of one. The answer is in the riddles section. Pen and ink illustrations. 52 pages.

BIOGRAPHICAL

Artist on his island. A study in self-reliance.

Randolph W. Johnson. Park Ridge, New Jersey: Noyes Press, 1975.

Sculptor Randolph Johnson carved his workshop out of the sand and palm trees of Abaco. In 1950 this artist withdrew from what he termed the "Megamachine", of modern civilization to a more self-reliant existence in The Bahamas. His diary entries from $1950^{\circ}-1974$ create a portrait of his island endeavours. One of his bronze monuments, The Bahamian Woman, can be seen in Rawson Square, Nassau. Illustrations, photographs. 186 pages.

Cocaine use: the accident of my life.

Carlton Robinson. NY: Vintage Press, 1989.

Carlton Robinson's candid autobiography reveals his addiction and rehabilitation. The effects of the drug trade on The Bahamas and its people and recommended solutions to the problem of drug trafficking are explored. 144 pages. 


\section{Hermit of Cat Island.}

Peter Anson. London, England. Barns and Oates, 1958.

Fra Jerome, who began his life as John Cyril Hawes, became Monsignor Hawes- the Hermit of Cat Island. Pages from diaries, letters, drawings, and photographs bring to life this unique personality. Of special interest are the churches Hawes designed; he was also an architect. The Hermitage, which he built atop Mt. Alvernia, Cat Island, was and continues to be a frequent site for visitors. Includes line drawings, photographs, an appendix of buildings designed by Hawes and an index. 212 pages.

\section{Letters and other messages from the heart. Behind the facade of a Bahamian}

\section{Methodist minister.}

Colin Archer. Nassau, Bahamas: ColMAR Pub., 1997.)

Dr. Archer, who was once a newspaper columnist and radio host as well as a psychotheologian, psychotherapist and Methodist minister, shares his personal correspondences as they relate to his life in the Methodist Church of The Bahamas. 250 pages.

\section{My Life.}

Sir Leonard Knowles (Former Chief Justice of The Bahamas). [s.1], [s.n.],[n.d.].

A former Chief Justice takes the reader on a tour of his life.

Central America, Africa, Israel, Egypt and Alaska are sites visited oưtside

of the Supreme Court of The Bahamas. 96 pages.

\section{My political memories.}

Henry Milton Taylor. Nassau, Bahamas [s.n.], [n.d.].

Mr. Taylor, a Bahamian and descendant of an old Loyalist family, served The

Bahamas from 1946 to 1972 . He co-founded and became the first party Chairman of the Progressive Liberal Party. His political memories reflect the consciousness of the developing nation. 410 pages.

\section{My religious memories.}

Henry Milton Taylor. Nassau, Bahamas [s.n.], [n.d.]. Another memoir in Mr. Taylor's series of memories. His personal history is interwoven with a history of Long Island and Nassau. His conversion to Catholicism is an important event. Includes poems and stories. 286 pages.

\section{Out-Island doctor.}

Evans Cottman. London, England: Hadder and Stoughton, 1979.

In the summer of 1939 a small town American finds his way to True Blue, Crooked Island and begins a new mission as "doctuh" to the people of the islands of The Bahamas. Naturally, his life is transformed as he is engaged with the island people and establishes a reputation for himself. Pen and ink illustrations.

248 pages. 
Reminiscences of an island teacher. Life in The Bahamas 1948-1953.

Jack Ford. Decatur, Illinois: White Sound Press, 1992.

Green Turtle Cay, Abaco, is the setting of this English teacher's five year Bahamian sojourn. Through Ford's personal journals, edited by Jack Handy, the reader can share a bit of Bahamian history and come to realize the charm of the island. Includes photographs and index. 104 pages.

Salute to friend and foe: my battles, sieges and fortunes.

Etienne Dupuch. Nassau, Bahamas: The Tribune, 1982.

A colour photograph of Sir Etienne, in full-dress uniform of the Sovereign and Military Order of the Knights of Malta, depicts the essence of his story. This book complements the Tribune Story, a reminiscence of the Dupuch family and their publications. In Salute..., Sir Etienne tells his story of World War I and the years that followed. Photographs. 208 pages.

\section{Turning the tide. One man against the Medellin Cartel.}

Sidney Kirkpatrick and Peter Abrams. New York: Onyx, 1992.

Richard Novak went to Norman's Cay to study the hammerhead shark, he found himself chasing down Carlos Lehder, kingpin of Colombia's cocaine empire and the Medellin Cartel. Novak is instrumental in the demise of Lehder. His story is a truelife thriller. Photographs. 319 pages.

\section{Tuskegee Ra! Ra!}

Cleveland W. Eneas. Nassau, Bahamas: Commercial Print Works, 1986.

At the age of 16 Eneas began his studies at Tuskegee Institute High School. Later he received a college degree from the same institution. This "autobiography of my youth," is a witty but reverential account of school days in Alabama laced with a Bahamian perspective. Photographs. 125 pages.

\section{Woodes Rogers: privateer and governor.}

G.E. Manwaring. Nassau, Bahamas: The Dean Peggs Research Fund, 1957. Captain Woodes Rogers, the first Royal Governor of The Bahamas, formerly privateer, the precise date of his birth unknown, was regarded as an elusive personality. Accounts of his life are both romantic and picturesque. An episode recounting Rogers' rescue from an uninhabited island is reputed to be the basis for Robinson Crusoe. Illustrations. 49 pages. 
Abaco, the history of an out island and its cays.

Steve Dodge. Decatur, Illinois: White Sound Press, 1983.

This book concentrates on the heritage of Abaco and its cays. Mr. Dodge states in the preface, "This book was written to fill some of the voids in our knowledge of the Bahamas..." The final chapter entitled, Contemporary Abaco, is of particular interest, as it highlights the contrasts in culture that make Abaco unique. Line drawings, illustrations, photographs. Includes notes, an Essay Describing Selected Sources, a list of maps and illustrations and an index. 172 pages.

\section{Arawaks and Astronauts: twenty years on Eleuthera.} Kjeld Helweg-Larsen. London, England: Jarrolds, 1970.

Helweg-Larsen was a travel writer who spent his life in the West Indies. For more than twenty years he made Governor's Harbour, Eleuthera his home. He owned an art and antique gallery there. Notable historical events are chronicled, including a visit from three Apollo astronauts in 1969. As for the Arawaks, he claims there are no living descendants on the islands. Photographs. Includes index. 192 pages.

\section{Bahamas: a family of islands.}

Diane Gail Saunders. London: Macmillan Caribbean, 1993 (1988, 1990).

A tour guide to the Family Islands. For each island there is a bit of history, the mention of a unique quality and all the information a tourist visiting the islands should need. Colour photographs, maps, tourist information. Includes bibliography. 203 pages.

\section{Eleuthera: the island called freedom.}

Everild Young. London, England: Regency Press, 1966.

The author makes two claims about Eleuthera: It is where Bahamian history actually begins, as the first settlers arrived there, and it is the most scenically beautiful island in The Bahamas. "The Company of the Eleuthera Adventurers," William Sayle's seventeenth century Utopian dream is described, including a copy of the Articles and Orders written in 1657. Photographs. 201 pages.

\section{Exuma Guide: a cruising guide to the Exuma Cays.}

Stephen J. Pavlidis. Brookfield, Wisconsin: Seaworthy Publications, 1995.

Besides being a meticulously detailed cruising guide, this book includes a history of the Exumas, and an introduction to the interesting species of flora and fauna that are uniquely Bahamian and live in the Exumas. An entire chapter is dedicated to the Land and Sea Park. Photographs, maps, recipes. Includes references, appendices, and index. 216 pages. 
Great Inagua.

Margery Erickson. Garrison, New York: Captive Press, 1987.

An absorbing story of the Erickson family who went to Inagua to restore the salt industry and turn the prosperity of the island around. This is a detailed and intimate portrait of family life and island life that will hold the reader's interest to the end. Pen an ink illustrations by the author, photographs. Includes index. 295 pages.

Homeward Bound: a history of the Bahama Islands to 1850 with a definitive study of Abaco in the American Loyalist plantation period.

Sandra Riley: Miami, Florida: Island Research, 1985.

"In the beginning...Enigma," the introductory chapter examines the geological theory of the creation of The Bahamas. The true natives of the islands, the parrots and flamingoes come, next then we meet the people. This thoroughly researched history is people centred. A list of surnames from Woodes Rogers' census, 1731, a chart listing the emigrants, complete with occupations, who arrived in Abaco during the loyalist period, 1783 to 1821 and a slave register from 1834 are a sample of the documents included in the appendix. Photographs, maps, pen and ink illus trations. Includes extensive notes, appendix, bibliography and index. 308 pages.

Innocent Island: Abaco in The Bahamas.

Zoe Durrell. Brattleboro, Vermont: Durrell Publications, 1972.

Abaco, as it has been affected by all of The Bahamas, as it becomes a nation. Book III looks closely at Treasure Cay, describing and illustrating the flora, fauna, and sea life. Pen and ink drawings. Includes notes and bibliography. 157 pages.

Inside Grand Bahama. The Insider's Guide.

Dan Buettner. Atlanta, Georgia: Fair Prospect Press, 1990.

The insider, Dan Buettner, an expatriate who claims to have visited 125 countries, chose Grand Bahama Island as his home over a decade ago. The reader is taken on excursions throughout the island. Distance from Lucaya along with recommended transportation are detailed for each excursion. Personal anecdotes embellish each tour. Activities, restaurants, and accommodations are recommended. Pen and ink drawings. 168 pages.

Island Expedition. School at Sea. Education in Nature.

Dragan and Nicholas Popov, editors. Nassau, Bahamas: Island Expedition, 1997. The Popovs came to The Bahamas as children. Since 1985 they have been taking children and young adults on educational expeditions throughout The Bahamas. Their publication is a multi-lingual, multi-cultural endeavour. Photographs. Includes index, bibliography, glossary and calendar of events for 1997-2007. 208 pages. 
Isles of Eden: life in the Southern Family Islands of The Bahamas.

Harvey Lloyd. Akron, Ohio: Benjamin Publishing Company, 1991.

An impressive pictorial celebrating the Columbus Quincentennial. Images and

interviews of Bahamians from San Salvador and the southern islands, beginning about 90 miles southeast of Nassau, are featured. Colour photographs. 91 pages.

\section{Mystical Cat Island.}

Eris Moncur. Miami, Florida: Northstar Press, 1996.

A well designed, colourful guide to Cat Island. The book includes history, culture, bush teas, trees, wildlife, bird watching, useful general and touring information.

Colour photographs. 56 pages.

\section{Paradise Island story.}

Paul Albury. London, England: Macmillan, 1984.

Historic Nassau harbour separates Paradise Island from New Providence.

Although an adjunct to New Providence, this tiny island has a colourful history influenced by wealthy and extravagant entrepreneurs who have shaped the development of Paradise as a tourist haven. Photographs, maps, illustrations. Includes notes and bibliography. 121 pages.

\section{Rum Cay, my home.}

Delores Wilson. Nassau, Bahamas: Delores Wilson, 1992.

Pineapple once brought people and prosperity to Rum Cay. Legends of mermaid combs which, if obtained, promise instant wealth, are part of the Rum Cay story. Delores Wilson shares memories of her early years and her return - complete with a gallery of Rum Cay residents and their descendants. Photographs, illustrations. 51 pages.

San Salvador, the forgotten island.

Pedro Gran Triana. Madrid, Spain: Ediciones Beramon, 1987.

A bi-lingual publication written in English and Spanish by a native Cuban who was fascinated with the journey of Columbus to Salvador. Columbus' exploration of San Salvador is the focus of the book. Of particular interest is the synoptic chart related to the identification of Guanahani (San Salvador) as described by Columbus. Colour photographs, maps, charts. Includes bibliography and index. 79 pages (each edition).

\section{Strangers no more: anthropological studies of Cat Island, The Bahamas.}

Joel Savishinsky, editor. Ithaca, New York: Dept. of Anthro., Ithaca College, 1978. This compilation of ethnographic fieldwork took place in January and February 1977 by the editor and twelve undergraduate students from Ithaca College. Topics include: Childhood Socialization, Bahamian Women, Alcohol Consumption, Bush Medicine, to name a few. Drawings. Brief references included after each study. 350 pages. 
Turks and Caicos Islands. Lands of Discovery.

Amelia Smithers. London, England: MacMillan Education, Ltd., 1995 (2nd ed.).

Beyond the Bahamas lie neighbouring islands, the Turks and Caicos. This

small guide is for visitors and lists all of the local tourist attractions. Short

chapters on the history and natural history of the islands set the scene.

Colour photographs and maps. Includes bibliography. 95 pages.

GOVERNMENT $* * * * * * * * * * * * * * * * * * * * * * * * * * * * * * * * * * * * * * * * * * * * *$

Bahamian symbols: the first five centuries.

Whitney Smith. Nassau, Bahamas: Ministry of Home Affairs, 1986.

Bahamian flags, seals, coats of arms, and other emblems marking symbolic acts.

This book imparts an understanding of the significance of certain designs and colours in interpreting the history of the nation. Illustrated. Includes glossary and notes. 109 pages.

\section{Cops and kidnappers.}

C. Monty Ritchie. New York: Vantage Press, 1984.

An account of the kidnapping of the four year old daughter of the manager of a

Royal Bank in Freeport, Grand Bahama. Insight into the Bahamian criminal justice system is revealed as the case unfolds and the kidnappers are apprehended and brought to trial. 202 pages.

History of The Royal Bahamas Police Force. Serving The Bahamas for 150 years.

C. Gabrielle Pratt. Nassau, Bahamas: Royal Bahamas Police Force, 1990.

The Bahamas Police Force was formed in 1840, almost all were former slaves and were former night guards who provided security for the island of New Providence. Earlier history from beginning in 1729 until 1990 is traced along with key officers. Photographs and drawings. Includes bibliography. 137 pages.

\section{Postage stamps and postal history of The Bahamas.}

Harold G. D. Gisburn. London, England: Stanley Gibbons, 1950.

A fascinating chronology of postal history with detailed descriptions of the printing and issuance of postage stamps in The Bahamas. Nassau's undersea post office, inaugurated in 1939, which stamped, cancelled and posted letters from the sea floor is a unique event which is documented in this book. Includes appendix and index. 144 pages.

Statue law of The Bahama Islands 1799-1987.

Ralph Hone, editor. London, England: Waterloo and Sons, Ltd., 1987 (rev. ed.). A revision from the 1965 edition. It consists of eight volumes and a supplement. The Constitution and Constitutional matters begin volume I. Legislature and The Administration of Justice follow. Interpretation is included. Volume VIII includes an alphabetical list of short titles in volumes I to VII. 5384 pages. 


\section{Bahamas in slavery and freedom.}

Howard Johnson. Kingston, Jamaica: Ian Randle Publishers, 1991.

Bahamian social and economic history differs from that of other British Caribbean countries. Since the sugar based plantation system was not the major source of income, a mercantile elite developed. This history examines the Bahamian experience as it fits into a wider comparative framework. The first six chapters look at the task and self-hire systems during slavery and the evolution of long-term labour contracts. Immigration and labour migration are other topics addressed. Includes notes, index, acknowledgments. 184 pages.

\section{Discovery of a nation.}

Michael Symonette. Nassau, Bahamas: Management Comm. Services, 1973. Michael Symonette stated it best, "This is a non-history of the Commonwealth of The Bahamas. I wanted to provide a non-technical summary of the major events and periods of Bahamian history to mark our independence - an objective Bahamian viewpoint." Considered a "twinkled-eyed" guide to 500 years of Bahamian history. Photographs, illustrations. Includes bibliography. 40 pages.

\section{Early settlers of The Bahamas and colonists of North America.}

A. Talbott Bethell. Holt, Norfolk, England: Rounce \& Wortley, 1937.

Names and numbers of early settlers and the hardships they experienced compromise this personalized history. Brief historical background is given relating to the Colonies and the events leading up to the American Revolution. Statistics, dates, lists and biographical sketches make this book a good source for the researcher. 218 pages.

\section{Faith that moved the mountain.}

Randol Fawkes. Nassau, Bahamas: Randol Fawkes, 1979.

Sir Randol's account of Bahamian independence. He has related the milestones toward the achievement of internal self government. Mr. Fawkes was involved in a number of civic, political and fraternal organizations which fought for social and economic justice. His description of the Duke of Windsor, when he was Governor of The Bahamas, and the plight of the labouring class is particularly telling.

Photographs. 292 pages.

\section{God save the queen God save me.}

Rupert Missick. Nassau, Bahamas: Family Island Press, 1973.

Personal essays about island life and growing up in Nassau, "Growing pains" reads like the narration of a Bahamian Huckleberry Finn. This witty collection is an honest, enjoyable look at the effects of colonialism. 53 pages. 


\section{Historic Nassau.}

Diane Gail Saunders. London, England: Macmillan Caribbean, 1979.

This is the first significant work devoted to the growth and development of Nassau. It traces the city's beginnings and major influences which brought about growth. The impact of Loyalists is still visible in the Georgian architecture and the design of the city. This book will change the way Nassau is viewed. Photographs, illustrations, maps. Includes bibliography. 54 pages.

\section{History of The Bahamas.}

Michael Craton. London, England: Collins, 1968.

The third edition of this book was published in 1986 after having been out of print for nearly ten years. A comprehensive work, this edition was updated with new maps, illustrations and bibliographic additions. History is narrated until 1985. The final chapter entitled. "The Pindling Era, 1968-1985" analyzes the PLP era for Bahamians presenting both positive and negative aspects. Photographs, illustrations, maps. Includes extensive bibliography, appendices, and index. 332 pages.

\section{Independence Bahamas.}

Photo-graphic Company with WJL Gibbons. Nassau, Bahamas: Photographics, 1974. A colour photo essay documenting Independence. It begins with the arrival of His Royal Highness the Prince of Wales. Images of dignitaries, spectators and celebration as the Union Jack is lowered for the last time in The Bahamas. Includes the text of the National Anthem of The Bahamas, Symbols of independence, the flag and the coat of arms. 33 pages.

Islanders in the stream. A history of the Bahamian people. Volume I.

Louise Craton and Gail Saunders. Athens, Georgia: University of Georgia Press, 1992. Volume one is from Aboriginal times to the end of slavery. Considered the first comprehensive chronicle of the Bahamian people which explains the evolution of a national identity outside of the Eurocentric context which frequently forms the basis for Caribbean histories. Published to coincide with the Columbus Quincentennial. Illustrations, maps. Includes copious notes and index. 455 pages.

\section{Land of Pink Pearl or recollections of life in The Bahamas.}

Louis Diston Powels. London, England: St. Dunston's House, 1888 (Reprint -UMI). In the summer of $1886 \mathrm{Mr}$. Powels was appointed to the post of stipendiary and circuit justice in the Bahama Islands. He had next to no knowledge of the islands and could find little information about them, with the exception of Nassau as a winter resort for Americans. His journey began on October 4th, 1886. His frank observations of colonial injustice are balanced with delightful descriptions of the people and the islands he encounters. Includes appendix and a facsimile of a book catalogue from 1887. 321 pages. 
Off der top. The best of Sideburns. A cartoon history of contemporary Bahamas. H.E. Stanley Burnside. Nassau, Bahamas: Nassau Guardian, 1983.

A collection of editorial cartoons dealing, for the most part, with The Bahamas, but satirizing international issues as well. Some of his pet topics are: politics, sports, crime, international affairs, religion, death, and business. "Sideburns" made its debut in the Nassau Guardian in July 1979. For a time, Mr. Burnside served as an art lecturer at The College of the Bahamas. 256 pages.

People who discovered Columbus. The prehistory of The Bahamas. William F. Keegan. Gainesville, Florida: University Press of Florida 1992.

A portrait of the Lucayan Tainos, a culture that became extinct almost 500 years ago. The author links archaeological field data and historical documents to present characteristics of the Lucayans in their island environment. Of special interest is a reconstruction of Columbus' voyage and a controversial theory about where Columbus actually landed. Illustrations, maps, graphs. Includes bibliography, index. 280 pages.

Social life in The Bahamas 1880s-1920s. (BGCSE History)

Gail Saunders, Nassau, Bahamas: Rosebud, Ltd., 1996.

A BGCSE theme book- History. A rigid class system continued into the twentieth century in The Bahamas. Poverty was prevalent throughout the islafads and an oppressive labour system developed benefiting the mercantile elite. Topics covered include: the structure of society and lifestyle, class, work and leisure, culture, religion, housing, and diet and health. Reading list and Things To Do included at the end of each chapter. Illustrations, photographs. Includes topical bibliography. 74 pages.

\section{Story of The Bahamas.}

Paul Albury. New York: St. Martin's Press, 1976.

Dr. Albury was once the President of the Bahamas Historical Society. Although a history, this account of The Bahamas reads like a story. The chapter "Hard Times," begins by revealing the 1926 theft of the colony's bullion reserves from the Currency Commission vault. Several other economic disasters soon followed. Recovery and later, independence, emerged in a colony which overcome adversity. Colour photographs, photographs, illustrations, maps. Includes Sources and Suggestions for Further Reading and index. 294 pages.

\section{Unicorn in The Bahamas.}

Rosita Forbes. New York: E.P. Dutton, 1940.

A very personal history of the author's travels and time in The Bahamas, especially living in Eleuthera, however, most of the islands are mentioned. The chapter, There Must be Unicorns, presents an insight into Rosita Forbes whose enthusiasm for travel was inspired her desire to find a unicorn. Photographs. 244 pages. 


\section{Brother for Sale.}

Jehan and Darius Unwala. Nassau, Bahamas: Jehan and Darius Unwala, 1996. Jehan Unwala is the youngest Bahamian to have published a children's book His older brother Darius, is the illustrator. This clever story even includes a hungry little potcake named Bones. Colour illustrations. 24 pages.

\section{An evening in Guanima.}

Patricia Glinton. Nassau, Bahamas: Guanima Press, 1993.

These Bahamian folk stories are a tribute to Cat Island, once known as Guanima, birthplace of the author. Thirteen tales, including adventures of B'er Bouki and Rabbie and the Master Trickster are told in hilarious dialogue, in keeping with the oral tradition from which they were derived. Illustrations, notes, riddles. 160 pages.

\section{Back home: an original anthology.}

Susan J. Wallace, London, England: Collins-Longman 1975.

One of several anthologies by well known Bahamian educator, Susan J. Wallace. Stories, plays and poems, some written in dialect, depicting aspects of Bahamian life and humour are appropriate for both young and sophisticated readers. Each entry ends with a series of questions. Pen and ink illustrations. 96 pages.

\section{Bahamas songs and stories: a contribution to folklore.}

Charles L. Edwards. Millwood, New York: Kraus Reprint Company, 1976, reprinted with permission of The American Folklore Society.

Volume III of the Memoirs of the American Folklore Society, originally published in 1895. This book is particularly interesting because parallels between American, native African and Bahamian folklore are indicated in the collection. At that time, the author noted in his study, that in the Bahamian islands, there existed a "striking homogeneity...in the life and surroundings of the people." This little book is a treasure for Bahamian folk-studies. Photographs. Includes introduction, appendix and notes. 111 pages.

\section{Bahamian art 1492-1992.}

Patricia Glinton. Nassau, Bahamas: Financial Corp. of The Bahamas, Ltd., 1992. A celebration of the visual arts of The Bahamas. Published in commemoration of the Columbus Quincentennial. The book is divided into four sections: The Meeting of Two Worlds, New Foundations, The First Wave, The Generation of '80s. Winslow Homer, Alton Lowe, Brent Malone, Amos Ferguson, Stan Burnside, Antonius Robers, Eddie Minnis, and Malcolm Rae are some of the featured artists. Includes index and acknowledgments. 103 pages. 
Bahamian proverbs.

Basil Peek. Nassau, Bahamas: The Providence Press, 1949. Reprinted 1966, 1971.

"Time longer dan rope." A small collection of short proverbs illustrated with simple pen and ink drawings by the author. 54 pages.

Flight of the spirit: Antonius Roberts a portrait of a Bahamian artist.

Patricia Glinton-Meicholas. Nassau, Bahamas: Guanima Press, 1996.

Antonius Roberts in considered one of the Bahamian "Masters." Mr. Roberts'

work has earned him international acclaim. He is also a respected teacher who has inspired creative talent in others. An interview with the artist and comments from fellow artists and collectors provide an insight into the man. Includes biographical chronology and acknowledgments. 64 pages.

Island Heritage. Architecture of The Bahamas. The drawings of Robert Douglas. Robert Douglas. Nassau, Bahamas: Darkstream Publications, 1992.

The author is an architect who was trained at the Oxford School of Architecture in England. His drawings and commentaries represent the building history of The Bahamas. Bahamian architecture is the result of imported styles adapted to serve climate and available materials. The Classical style came over with the English, the plantation style home was imported from Charleston, which had been settled by Barbadians. Loyalists brought the New England wooden structure. The legacy of these immigrants can be seen throughout the islands. Nassau will be transformed after reading this book. Drawings. Includes bibliography. 96 pages.

\section{Laughin at Wesef. Book one, skits.}

James Catalyn. Nassau, Bahamas: Nassau Guardian, 1986

Bahamian dialect and word play characterize the comedic episodes throughout Mr. Catalyn's work. He is a master of Bahamian nuance. The short skits are written for two, three and four characters. Line drawings illustrations. 118 pages.

\section{Nostalgic Nassau. Picture Postcards 1900-1940}

Shelley Boyd Malone. Nassau, Bahamas: Nassau Bahamas Nostalgia, 1991. A collection of picture postcards from days gone by. A wide variety of subjects representing the Nassauvian venue: touristic scenes of Bay Street, children on a mule cart, fishing boats, sponge trimmers, sisal and a traveling saleswoman with her turkeys roosting on top of her head. Historic commentary accompanies each image. Most photographs are colour tinted. 64 pages.

Runnin' sheep: a collection of stories from Long Island, Bahamas, 1900-1950. Cindy Ambrister. Nassau, Bahamas: Guanima Press, 1995.

This collection of short stories is a memorial to the author's mother, who narrated the events upon which the stories are based. Cartwright's Long Island is the setting. Part of the Long Island heritage included 'sheep runners,' hence the title of the book. Eleven stories, including a hurricane, life at school and a father gone off to work on the contract, make this a personal contribution to the preservation of Bahamian life and lore. Pen and ink illustrations. Acknowledgments. 94 pages. 


\section{Shallow Sea.}

Neil Ruzic. Madison, Connecticut: St. Clair Press, 1992.

An American idealist-entrepreneur, his best friend and a Bahamian fisherman are forced into an action-packed Caribbean plot. Political corruption, idealism and intrigue visit their tropical paradise and their idyllic, island life is disturbed by a year of events dominated by bizarre battles and revenge. Neil Ruzic, who is a journalist and scientist, has written ten books; this is his first novel. 537 Pages.

\section{Still standing.}

Michael Pintard, Nassau, Bahamas: Guanima Press, 1995.

This body of work is divided into poems of concern: Concerning Love, Concerning Struggle, Concerning This and That. Bus Ride, will amuse jitney riders. The signature poem, Still Standing, expresses Mr. Pintard's response to public opinion. Illustrated by P. Neko Meicholas and Eric Ellis. 127 pages.

Under the Sunday tree. Poems.

Eloise Greenfield. Paintings by Amos Ferguson, New York: Harper, Trophy; 1991. Amos Ferguson's paintings brilliantly accompany the light-hearted poems in this collection. It is difficult to determine which came first, the painting or the poem. Colour illustrations. 39 pages.

\section{Wind from the Carolinas.}

Robert Wilder. London, England: W. H. Allen, 1964.

The classic novel of aristocratic Georgian, Carolinian and Virginian Loyalist families who settled in The Bahamas. Their dramatic migration was fraught with uncertainty and failure. Plantation life could not successfully be recreated on the Family Islands of The Bahamas. The adaptation of several generations of the Cameron family to their new environment and the new dynasty they created is the basis of this exciting work of historical fiction. 639 pages.

\section{Woman take two. A play in three acts.}

Telcine Turner. New York: Vantage Press, 1987.

A three-act play of passion set in pre-independent New Providence. These characters are embroiled in love and greed. While Miss Turner's prose often expresses joy, this play examines the darker side of the human character.

93 pages.

\section{NATURAL HISTORY}

\section{Bahamian landscapes: an introduction to the geography of The Bahamas.}

Neil Sealey, London, England: Collins Caribbean, second edition, Nassau, Bahamas: Media Enterprises, 1994.

What is the Bahamas Platform? Mr. Sealey, a former lecturer at The College of The Bahamas, begins his book by defining that concept. The first edition is a compilation and presentation of the work of other people. The second edition has been updated to include more recent research. The clear presentation of information 
will instruct both novice and scientist. Photographs, illustrations, maps, graphs. Includes bibliography and index. 126 pages.

\section{Bahamas today. An introduction to the human economic geography of} The Bahamas.

Neil E. Sealey. London, England: MacMillan Caribbean, 1990.

A complement to Bahamian Landscapes. Plants and animals are included in the landscape. The author explains how human adaptation and manipulation of the environment and social organization have become interdependent to provide an economic framework supporting the inhabitants of The Bahama Islands. This book examines simple ecosystems and complex agricultural activities. Manufacturing, trading as well as tourism are included in this infrastructure. The final chapter examines this impact on the natural habitat. Photographs, illustrations, maps, graphs. Includes bibliography and index. 120 pages.

\section{Birds of New Providence and The Bahama Islands.}

P.C.C. Brudenell-Bruce. London, England: Collins, 1975.

Ninety three species of birds are included in this guide. Several categories of birds are classified: Residents, Summer Visitors, Winter Visitors, Passage Migrants, Vagrants and Unclassified. Each bird described is designated with a status. Colour illustrations, maps. Includes appendix of "Accidentals," song chart of some common songbirds and index. 142 pages.

\section{Blue Holes of The Bahamas.}

Robert Palmer. London, England: Jonathan Cape, 1985.

Blue holes or underwater caves are scattered throughout Grand Bahama and Andros. A first-hand account of the opening of the Blue Hole caves and the 1984 Zodiac Expedition led by the author, reveal discoveries of heretofore undisturbed creatures. The contributions to the field of marine biology are significant. An insight into the wonders and hazards of Blue Hole diving is also described. Colour photographs, maps. 184 pages.

\section{Ephemeral islands.}

David Campbell, London, England: Macmillan, 1978.

This book defines the climate, geology, biology and social conditions in the islands of The Bahamas and points out the environmental stresses impacting them. Mr. Campbell begins this study in his own backyard, recounting his own observation of a hummingbird. From this point the view of the scene expands from familiar habitat to the geologic history of the islands. This is a comprehensive examination of the environment, even ants and flies are included. The text is beautifully written. Photographs, illustrations, maps. Includes bibliography and index arranged by subject. 151 pages. 
Fishes of The Bahamas and adjacent tropical waters.

James E. Bohlke and Charles Chaplin. Austin, Texas: University of Texas Press, 1968,

1993.

From the collections in the Academy of Natural Sciences of Philadelphi collected by the authors and their families and friends since 1946, and collections at the Institute of Marine Sciences of the University of Miami. The book is limited to inshore species, in the more shallow water at the edge of the bank and within the depth range of a SCUBA diver. The book is encyclopedic and scientifically oriented, as classification is in Latin nomenclature. Common names are also included. Outline drawings of representative examples of the fishes, labelled with both names, allow the reader to make a preliminary visual identification. Coloured black and white photographs, illustrations, maps, Includes glossary, extensive bibliography and index. 771 pages.

\section{Flora of The Bahama archipelago (including the Turks and Caicos Islands).}

Donovan and Helen Correll. Germany: J. Cramer, 1982, 1996.

A comprehensive, technical botanical reference. Arrangement is by Latin nomenclature; common terminology is included. Plant communities are described and brief discussions of agriculture, bush medicine and poison plants can be found in the introduction. The Summary of the Flora of The Bahamas Archipelago lists 1,350 species of flowering plants and ferns, with $8.83 \%$ considered to be endemic to the islands. All of them are included in this book. Illustrations, maps. Includes distribution table, itinerary of collection, selected references, glossary, appendix of types of fruits, roots, and stems, explanation of floral diagrams, and index. 1692 pages.

\section{Native trees of The Bahamas.}

Jack Patterson. Hope Town, Abaco: Jack Patterson, 1977.

Tree, as defined in this book is understood to mean, "a woody stem that occasionally or often grows, unsupported and erect, to a height of eight to ten feet or more." Fifty-three families of species are represented. The reader is reminded that the common names vary from island to island. The division is by: 1) Palms, 2) Red, Cedar, Pine, Casuarina, 3) Simple Alternative Leaves, 4) Simple Opposite Leaves, 5) Compound Leaves. Introduced species, some common shrubs and plants, and the distribution of Bahamian trees complete the book. Line drawings, map. Includes an alphabetical list of species. 124 pages.

\section{Natural history of Carolina, Florida, and The Bahama Islands. 2 volumes.}

Mark Catesby. Savannah, Georgia: Beehive Press, 1974. Originally published 1729-47. Introduction by George Frick and notes by Joseph Ewan. A facsimile of Mark Catesby's magnificent 18 th century natural history catalogue of birds, beasts, fishes, serpents, insects, and plants. The reproduction was copied from a third edition located at the Boston Athenaeum. Catesby's own history is rather mysterious, yet he has been referred to as the "Colonial Audubon."This work is still regarded as one of the great achievements of Anglo-American science. The set consists of two 
illustrated catalogues and fifty facsimile colour plates. The text is written in both English and French. Includes an index of Modern English Names and an Index of Scientific Names. A select bibliography of Catesby's Work and general works are included with this edition. Each volume-109 pages.

Reef coral identification: Florida, Caribbean, Bahamas.

Paul Humann. Jacksonville, Florida: New World Publications, 1993.

An easy to use, in-depth guide to coral and marine plants. The book is divided into recognized groups which are indexed on the back side of the book cover. Directions for using the book along with types of coral reefs, structures, terms, abundance and istribution are explained in a few pages. Brilliantly coloured photographs make up the majority of the book. Common name is listed before Latin classification. Visual ID, abundance and distribution, habitat and behaviorand effect on divers, listed with each coral, provide the reader with essential information. Colour photographs, illustrations, maps, Includes index, personal record of sightings and an Appendix for marine plants. 253 pages.

Shells at our feet: an introduction to shelling in The Bahamas.

Mary Baker Moulding. Chicago, Illinois: Sea Scapers, 1967.

The author of the book states that the purpose of her book is to extend a warm welcome to the visitors of The Bahamas. While it is written with the casual sheller in mind, there is enough scientific information to make the book a substantial source. The text includes a How to Shell section and explains what is in a shell, as well as the Who's Who guide, includes Latin names. Colour photographs, illustrations. Includes "Conchological Terms," and bibliography. 104 pages.

\section{Underwater Bahamas.}

Bob Friel. Miami Beach, Florida: Blue Edge Publications, 1993.

A brilliant colour pictorial of life under Bahamian waters. The book informs the reader that, "Bahamian reefs are crowded wall to wall with samples from more plant and animal groups than can be found anywhere on land... It is an oasis in a desert of water everywhere." The author, who was the photographer as well, explains that he used many types of under-water photographic equipment to achieve the quality of the photographs represented in the book. The focus is on corals but there is a chapter on Blue Holes and A Bahamas Dive Operators and Service Listing. Text is brief and serves to support the photographs. Colour photographs, map. Includes index. 205 pages.

REFERENCE $* * * * * * * * * * * * * * * * * * * * * * * * * * * * * * * * * * * * * * * * * * * * *$

Bahamas handbook and businessman's annual.

Nassau, Bahamas: Dupuch Publishers, annual.

(Almost) everything anyone would ever want to know about The Bahamas. The first edition was published in 1960. Every year Dupuch Publishers write several new feature articles for the new edition. This handbook will advise newcomer and 
native alike where to find the essentials for functioning in the country: animal importation, banks, investment Information, ship registration, telephone and water rates to give an example. There is an explanation of the Bahamian governmental system including Cabinet Members and portfolios, Ministers of State and Senators, House of Assembly, Public Service Officials, and the Diplomatic Corps. A section is included for Freeport/Lucaya. Photographs, illustrations, maps, charts, advertisements. Includes index. 559 pages.

\section{Bahamas index and yearbook.}

Steve Dodge, compiler, editor. Decatur, Illinois: White Sound Press, 1987. An annual index to newspaper articles from the Nassau Guardian and the Tribune primarily dealing with substantive articles covering major developments in The Bahamas. Each citation includes an abstract. Each edition (in recent years) includes The Year in Review, Interviews, and a Seminar Report. The newspaper index includes an introduction explaining how to use the index. There are ten sections, each section includes an index. Includes End Notes and Works Cited. 266 pages.

\section{Literature of The Bahamas 1724-1992. The march toward national identity.} Anthony G. Dahl. Lanaham, Maryland: University Press of America, 1995.

The author claims this is the first in Bahamian culture because it is the first book to analyze the literary history of The Bahamas from the Arawaks to 1992. Of course, the literature and the history are intermingled. The author explains his intention "to put The Bahamas on the map of the Caribbean as far as literature is concerned and to give our country more cultural respect." The book is organized into chronological essays. Includes a bibliography at the end of chapter. At the conclusion of the book is a bibliography for both primary and secondary sources. Includes index. 219 pages.

\section{Sources of Bahamian history.}

Philip Cash, Shirley Gordon and Gail Saunders. London, England: Macmillan Caribbean, 1991.

A source book for Bahamian history assembled with students and researchers in mind. A selected group of sources have been made from available sources. The first part of the book, Peoples of the Bahamas, is a descriptive overview of the country. From that general perspective the story is developed in three different points of view: British, American and African. The fifth part of the book looks at The Bahamas from the end of slavery to independence. The final section of the book examines the progress of an independent Bahamas. One asset of the book is the questions to guide the reader to an understanding of conditions and circumstances of events, some require the reader to infer other aspects of the situation. Photographs, illustrations, charts. Includes a list of references by section, and an index. 374 pages. 


\section{Yachtsman's Guide to The Bahamas, includes Turks and Caicos.}

North Miami, Florida: Tropical Isle Publishers, annual.

Before the cruising begins, this helpful guide provides essential information: what you must know before using the guide, what your skipper must know, customs and immigration, wind and weather, vhf stations, Bahamas Defense Force, radio facilities, cruising facilities, diving facilities and approaches to The Bahamas. With that information intact, the yachtsman is ready to sail, island by island. Descriptions of the island including notable sites and landmarks along with approaches to harbours, tilitarian information, such as special notes, natural parks and rules, and sources of fresh water make this book an excellent source for the sailor.

Photographs, illustrations, maps, advertisements. Includes tide tables, 'Galley Guide,' Light List, index and chart index. 470 pages.

\section{SOCIAL}

Maximizing your potential. The keys to dying empty.

Myles Munroe. Shippensburg, Pennsylvania: Destiny Image Publishers, 1996. Dr. Myles Munroe is the founder and president of Bahamas Faith Ministries International, a network of ministries, with headquarters in Nassau. He has written several inspirational books. This book admonishes the reader to go beyond self imposed limitations. In the first sentence of the preface the author states, "The greatest threat to being all you could be is the satisfaction with who you are." Stories, aphorisms and principles direct the reader to live beyond barriers and reach outside of the 'norm.' 178 pages.

\section{Modern Bahamian Society.}

Dean W. Collingwood and Steve Dodge, editors. Parkers, IA: Caribbean Books, 1984. This book was written during the ' 80 s, perceived as a time of social transition in The Bahamas, during a time when the Bahamian spirit was becoming liberated. A positive time of nation building. A collection of essays written by Bahamians and non-Bahamian representing varied sectors of society address popular themes and provide the current reader with retrospective insight. Map, charts. Includes notes at the end of each chapter. 278 pages.

New Bahamians. Reflections on our national life since Independence.

Michael Symonette. Nassau, Bahamas: International Publishing Company, 1982.

Mr. Symonette, founder of the Bahamas Financial Digest, contemplates the issues confronting the new generation of Bahamians who have grown since Independence Day 1973. Of course, now, there is yet another generation and so it goes. These brief reflections examine the past, affairs at the time, ideals of youth and values of the Bahamian society. The book ends with a speculation about the election of, 82 . Afterword written by Sir Lynden Pindling. 132 pages. 
Psychologically speaking: attitudes and cultural patterns in The Bahamas. Mizpah Tertullien. Boynton Beach, Florida: Star Publishing Company, 1976.

The text of the book was taken from a weekly radio lecture series presented on ZNS, Radio Bahamas. It was a first of its kinds in The Bahamas and ran for nearly two years. Issues of daily life in the Bahamian world are addressed. Psycho-social aspects of identity and personality, especially family life, and the importance of the home environment on youth comprise the majority of the work. The chapter entitled Bahama Way is of particular interest. Includes bibliography and index. 244 pages.

\section{Quiet revolution in The Bahamas.}

Doris L. Johnson. Nassau, Bahamas: Family Islands Press, 1972.

Senator Doris Johnson was the first woman to run for the legislature; the first woman to be appointed to the Senate; and the first woman to be made a Minister in the Government. All of this after having made a plea to allow women to vote, eventually leading to emancipation in 1962. The author emphasizes the 'quiet' part of the revolution in The Bahamas. The intention of this work was to stimulate discussion about the direction of a newly independent country and about the concept of freedom itself. Photographs. Includes footnotes, appendices, bibliography, chronology of important dates in Bahamian history, and index. 178 pages. 